INTERNATIONAL JOURNAL OF

MULTIDISCIPLINARY STUDIES IN ARCHITECTURE

AND CULTURAL HERITAGE

\title{
Sustainable Development Strategies in Heritage Areas (Minia Governorate Case Study)
}

Samah Abd Al-Rahman Mahmoud, a Shaza Gamal Mohamed Ismail, b

Mohamed Abou-Shouk, $c$ and Chiresteena Adel Fathi, d, e, *

a Professor, Tourism Guidance Department, Faculty of Tourism and Hotels, Minia University b Professor, Tourism Guidance Department, Faculty of Tourism and Hotels, Helwan University c Associate

Professor, Tourism Studies Department, Faculty of Tourism and Hotels, Fayoum University

d PhD Candidate, Tourism Studies Department, Faculty of Tourism and Hotels, Minia University

e Office Director of the Dean of the Higher Institute of Languages for New Insurance

\begin{abstract}
National strategies for sustainable development (NSSD) are a tool to assist countries in overcoming these sorts of problems and start to strengthen their capacity for sustainable development. It is national strategy for sustainable development is 'a strategic and participatory process of analysis, debate, capacity strengthening, planning and action towards sustainable development .NSSD processes offer the opportunity to redress the balance between consideration of economic growth, environmental sustainability and social progress. They serve as a catalyst to assess the success of a country's existing strategies, plans and programmes, to identify constraints to integration of different sector objectives and means of overcoming them. They encourage a process of fair representation for the integration of different priorities into developmental processes, So The problem of the study lies in the lack of sustainable development plans in the preservation of the archaeological areas, therefore the study includes the positive impact of the upgrading of tourist heritage areas, and the benefits and benefits of economic, social and cultural resulting from this upgrading of these areas and the tourism link between them. Also Studying how to implement the sustainable development of the archaeological and heritage areas.

Keywords

Sustainable.

- Heritage.

- Development.

- $\quad$ Archaeological Sites.

Traditional.
\end{abstract}

\section{Introduction}

Sustainable tourism development is defined as a model form of economic developmentthat is designed to improve the quality of life of the host community, provide a high quality of experience for the visitors, and maintain the quality of the environment on which both the host community and the visitor depend.

Accordingly, tourism must be environmentally sustainable in both the natural and cultural environments to be economically sustainable. Sustainable tourism 
development requires the demand of tourists satisfied in a manner that destination continues to attract themwhilst meeting the needs of the host population with improved standards of living, yet safeguarding the destination's environment and cultural heritage.

Sustainable tourism development guidelines and management practices are applicable to all forms of tourism in all types of destinations, including mass tourism and the various niche tourism segments. Sustainability principles refer to the environmental, economic and socio- cultural aspects of tourism development, and a suitable balance must be established between these three dimensions to guarantee its long-term sustainability.

Sustainable tourism development requires the informed participation of all relevant stakeholders, as well as strong political leadership to ensure wide participation and consensusbuilding. Achieving sustainable tourism is a continuous process and it requires constant monitoring of impacts, introducing the necessary preventive and/or corrective measures whenever necessary.

Sustainable tourism should also maintain a high level of tourist satisfaction and ensurea meaningful experience to the tourists, raising their awareness about sustainability issues and promoting sustainable tourism practices amongst them (UNEP-WTO, 2005, P. 11).

Almost three elements interact to form the framework of tourism development in the domain of sustainability. These are tourism industry, environmental setting, and the community. Within the new concept of sustainable tourism, the tourism industry seeks a healthy business environment with a financial security, a trained and responsible workforce and attractions of sufficient quality to ensure a steady flow of visitors who stay longer and visitmore often. Tourism can benefit the community through cultural interaction, infusion of money, transfer of 
technology, environmental education, improved land use, creation ofworking opportunities and local business development. Those interested in natural environment and cultural heritage issues seek protection of the environment through prevention, improvement, correction of damage, and restoration, besides motivation of people to be more aware and therefore care for rather than use up resources.

On the other hand, community members seek a healthy place in which to live with adequate and clean water, health care, rewarding work, equitable pay, education and recreation, respect for cultural traditions and opportunities to make decisions about the future. The community can provide cultural interaction, visitor services, and local products. Some concernsthat may hold in common include: issues of access to destinations, cultural impact or commonuse of infrastructure and land use issues. According to the World Tourism Organization, threefundamental concepts underpin current approaches to sustainable tourism:

1. Tourism should be more sustainable in the way that it is developed and operated.

2. Sustainable tourism strategies and policies should reflect a two-way relationship: Impacts on tourism and Impact of tourism.

3. Sustainability and competitiveness are interdependent. Tourism is a quite complex sector, itinvolves many actors and it is linked to many other sectors (such as environment, culture, transport), it relies on public-private partnerships, it strongly affects host communities, and it includes intangible aspects. The main tourism products are "destinations" which offer to visitors the opportunity to experiment a variety of experiences.

\section{THE PROBLEMS OF THE STUDY:}


The problem of the study lies in the lack of sustainable development plans in the preservation of the archaeological areas; as well as the lack of linking the heritage sites despitetheir integration and diversity if included in conservation plans; despite the Egyptian efforts toprepare the heritage areas, but the share of heritage areas in Minia governorate of developmentefforts is still few.

Not to include the heritage areas in Minia Governorate World heritage list, although itis of exceptional international value and characterized by the availability of natural ingredientsand unique heritage and meet the requirements of the World Heritage List, which supports thepromotion of global.

\section{QUESTIONS OF THE STUDY:}

1. Are there conceivable policies and procedures to solve the problems and challenges facing sustainable development in the Church of the Virgin Mary in the village of Deir Jebel al-Tair and other archaeological sites?

2. What are the most effective policies and practices, if any, in order to activate the role of thecommunity for sustainable development in the archaeological areas in Minia Governorate?

3. Are archaeological sites available in Minia Governorate sufficient heritage elements to ensure inclusion in the list of world heritage?

4. Are there policies and procedures that will enable me to preserve my traces of the traces of the holy Family's route in Minia Governorate?

5. Have all the places visited in Minia Governorate in previous studies been adequately covered(in terms of the most important sources and books that dealt with the places in Minia and comment on them in terms of their effects and development)? 


\section{THE SIGNIFICANCE OF THE STUDY:}

The importance of the study is that it is:

- Focused on shedding light on the important archaeological areas in Minia Governorate, eachof them separately, and this is what was overlooked in the field of studies related to the upgrading of heritage areas.

- Ensure the positive impact of the upgrading of tourist heritage areas, and the benefits and benefits of economic, social and cultural resulting from this upgrading of these areas and the tourism link between them.

- Studying how to implement the sustainable development of the archaeological and heritage areas in the flight to Egypt in the province of Minia.

- proposes a vision for the development of the archaeological environment of the archaeologicaland heritage areas in the flight to Egypt in the province of Minia.

\section{OBJECTIVES OF THE STUDY:}

- Emphasize the heritage value of the heritage and archaeological areas in the province ofMinia.

- Identify the obstacles to development in the heritage and archaeological areas in thegovernorate of Minia.

- Analysis of the current situation and identification of development opportunities for theheritage and archeological areas, and the archaeological surroundings

- Link between the heritage and archaeological areas of tourism that follow 
INTERNATIONAL JOURNAL OF

MULTIDISCIPLINARY STUDIES IN ARCHITECTURE

AND CULTURAL HERITAGE

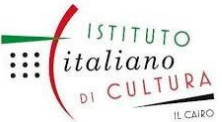

the work of aproposal for a sustainable development plan for these areas.

\section{LIMITATIONS OF THE STUDY:}

- Archaeological areas in the province of Minia and retired

1- The Church of the Virgin Mary in the village of Deir El-Garnous in

Maghagha.2- Maryam tree in Albanassa center Bani Mazar north of

Minia Governorate.

3- The Archaeological Church of the Virgin Mary, the village of Deir al-Tair Monastery in thecenter of Samalut, Minya Governorate.

4- Ashmounin area in Malawi.

- In addition to relying on the experiences of some developed countries in the field of sustainable development, and experiences of some developing countries in order to apply to the Arab Republic of Egypt as appropriate.

\section{METHODOLOGY OF THE STUDY:}

The study is based on a case study methodology that requires a complete analysis of allthe data and information collected in a scientific and objective manner, in order to reach the results for analysis and interpretation. This is done by observing and photographing the field visits to the study areas, Flight from Palestine to Egypt, analysis of the current situation and opportunities for development.

The descriptive analytic approach is used to describe and analyze the experiences of countries in their application of sustainable development in order to benefit from a proposal forsustainable development and to improve the heritage and 
INTERNATIONAL JOURNAL OF

MULTIDISCIPLINARY STUDIES IN ARCHITECTURE

AND CULTURAL HERITAGE

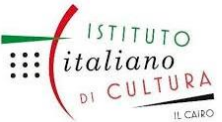

archaeological areas that The Holy Family visited during its flight to Egypt.

\section{PRINCIPLES OF THE SUSTAINABLE TOURISM DEVELOPMENT:}

The principles of sustainable tourism development are based upon recognizing change in the nature of tourism destination, scale, and rate of development, the assumption of management to attain long-term goals and responsibility for avoiding or minimizing impacts on the environment. The sustainable tourism development comprises the following major principles:

- Establishing ecological limits and standards that are more equitable.

- Reducing over consumption and waste.

- Avoiding the costs of restoring long-term environmental damage and contributes to thequality of tourism.

- Supporting wide range of local economic activities and avoids environmental damage by

considering environmental costs/values.

- Redistribution of economic activity and reallocation of resources to meet essential needs depending on achieving full growth potential and sustainable development.

- Controlling population and distribution of resources to ensure that the demographic developments are in harmony with the changing potential of the ecosystem.

- Sustainable use of basic resources natural ssocial and cultural and makes long term business sense by using new future options and non-renewable resources as possible. them and the environment in general but also improves the quality of the tourism 
experience (Nasreen Al-Lahham, 2007).

- Consulting stakeholders. Consultation between the tourism industry and local communities, organizations and institutions is essential if they are to work alongside each other and resolve potential conflicts of interest.

- Ensuring equitable access to the constrained resource and effectively use of technological effort through reorienting of technological efforts to relieve the pressure on basic resources.

- Controlling of carrying capacity.

- Maintaining and promoting natural, social and cultural diversity for long term sustainable

tourism, and creating a resilience base for the industry.

- Integrating tourism into planning. Tourism development which is integrated into

a national and local strategic planning framework, and which undertakes EIAs, increases the long term viability of tourism.

- Training of staff members. Integrate sustainable tourism into work practices, along with recruitment of local personnel at all levels, improves the quality of the tourism product.

- Marketing tourism responsibly. Marketing provides tourists with full and responsible information increases respect for the natural, social and cultural environments of destination areas and enhances customer satisfaction.

- Minimizing adverse impacts on basic resources.

- Involving environmental policy in management process to ensure environmental quality.

- Using an effective environmental audit system (Ragheb, Riham A, 2015, P: 3). 
INTERNATIONAL JOURNAL OF

MULTIDISCIPLINARY STUDIES IN ARCHITECTURE

AND CULTURAL HERITAGE

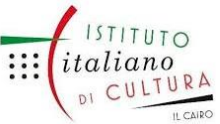

\section{SUSTAINABLE TOURISM DEVELOPMENT INSTRUMENTS:}

The sustainable tourism development comprises the following instruments as techniques employed to apply sustainable tourism development:

1) Area Protection: Various categories of the status of protected areas includes: national parks, wildlife refuges/reserves, biosphere reserves, country parks, biological reserves, areas ofnatural beauty and sites of special scientific interest.

2) Industry Regulation: Government legislations, professional association regulations, international regulations, control regulations, and self-regulation.

3) Visitors Management Techniques: Zoning, honey pots, visitors dispersion, channeled visitorflows, restricted entry, and vehicle restriction.

Environmental Impact Assessment: Overlays, matrices, mathematical models, cost benefit analysis, the material balance model, the planning balance, the planning balance sheet, rapid rural appraisal, GIS and environmental auditing.

4) Carrying Capacity Calculations: Physical carrying capacity, ecological carrying capacity, social carrying capacity, environmental carrying capacity, effective or permissible carrying, limits of acceptable change

5) Consultation / Participation Techniques: Meetings, public attitude surveys, stated preferencesurveys and contingent valuation method.

6) Codes of Conduct: Codes for the tourists, the industry, the host governments, and host communities.

7) Sustainability Indicators: Resource use, waste, pollution, local production, access to basic human needs and facilities, freedom from violence, access to the decision making process, diversity of natural and cultural lives. The tools of sustainability 
INTERNATIONAL JOURNAL OF

MULTIDISCIPLINARY STUDIES IN ARCHITECTURE

AND CULTURAL HERITAGE

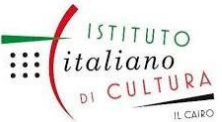

such as carrying capacity calculations, environmental impact assessment, and sustainability indicators, can be used to minimize the effects of tourism development to a point at which they can be excused. Accordingly, assessing elements for sustainability shall in a way reduce the significance or level of acceptance or tolerance of all other conditions. Throughout all stages of tourism development and operations, a careful assessment, monitoring and mediation program should be conducted in order to allow local people and others to take advantage of opportunities or torespond to changes.

In practice, sustainable development requires the integration of economic, environmental, and social objectives across sectors, territories, and generations. Therefore, sustainable development requires the elimination of fragmentation; that is, environmental, social, and economic concerns must be integrated throughout decision making processes in order to move towards development that is truly sustainable (The Concept of Sustainable Development : Definition and Defining Principles, Brief for GSDR).

\section{THE SUSTAINABLE SOCIETY:}

The concept of a sustainable society has been around for decades. In 1981, Lester Brown, founder of the World watch Institute, defined it as "one that is able to satisfy its needs without diminishing the chance of future generations. Over the years, this concept has evolved toencompass a broad range of social and environmental issues. Many activists picture a sustainable society as a Venn diagram of three overlapping concerns:

\section{En}

vir

on 
me

nt

Soc

ial

Eco

no

mic

In a sustainable world, each dimension works in harmony with the other. Today's citizens are given every opportunity to grow and thrive; tomorrow's resources are preserved and protected Nasreen al-Lahham, 2007).

\section{The First Practical Steps towards a Sustainable Society:}

Sustainability is a process of continuous improvement so communities constantly evolve and make changes to accomplish their goals. The initiatives and resources on this website have been selected to help you learn about ways to make your community healthier, safer, greener, more livable, and more prosperous, or How cities can get started with implementing the Sustainable Development Goals (SDGs) in cities(Ali Hesham,2013).

\section{Raise Public Awareness:}

Individuals cannot make sustainable choices unless they know what those choices are,and countries will not take direct action to promote sustainable practices unless they receive substantial pressure from citizens. Websites, speeches, movements and rallies all contribute toraising public awareness. 


\section{Promote Education:}

Promoting free and fair access to a quality education for all children, both girls and boys, produces a number of positive outcomes. It increases children's level of understanding about the environment; it empowers them to make personal choices about Family size and lifestyle; and, it provides the world with informed and productive citizens.

\section{Increase Government and Business Investment.}

New technologies and infrastructures, built using environmentally sound practices, have the potential to transform modern society. However, this is only possible if governments and businesses are willing to invest much-needed capital in their development.

\section{Conserve Resources and Eliminate Waste:}

Like it or not, the earth's resources are finite. Large-scale efforts to conserve energy and water will have an impact, but personal choices are just as important. The more steps we take to eliminate waste and needless consumption, the better off future generations will be.

\section{Re-Evaluate Values:}

Is the current culture of disposable consumerism, fossil fuel dependency and heavy automobile use what we hope to pass on to our children? Do we wish to overcome inequalitiesin education, standards of living and economic opportunity? Then our personal values, as well as our actions, must change (https://www.sustainabilitydegrees.com/what-is- $\quad$ sustainability/sustainablesociety/). 
INTERNATIONAL JOURNAL OF

MULTIDISCIPLINARY STUDIES IN ARCHITECTURE

AND CULTURAL HERITAGE

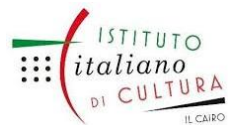

ISSN: $2735-4415$

VOLUME 3, ISSUE 2, 2020, $31-61$.

www.egyptfuture.org/ojs/

\section{The Sustainability Society Index (SSI):}

The Sustainable Society Index (SSI), a framework developed by the Sustainability Society Foundation, assess the level of progress toward sustainability in over 150 countries. Itranks each country in three "wellbeing dimensions":

Environmental Wellbeing: Nature and environment (e.g., air quality), climate and energy (e.g., greenhouse gas reduction) and natural resources (e.g., biodiversity). Human Wellbeing: Basic needs (e.g., safe water), personal and social development (e.g., gender equality) and health (e.g., clean water). Economic Wellbeing: Transition (e.g., organic farming)and economy (e.g., employment).

\section{$21^{\text {st }}$ Century Sustainable Society:}

What does a $21^{\text {st }}$ century sustainable society look like? Primarily, it is selfsufficient. Non-polluting, renewable resources provide the power to drive sustainable energy systems; more efficient farming techniques and new technologies improve yields; and, reduced consumption helps eliminate waste.

As a result, the environment can be preserved for future generations. Global temperatures could cease to climb, and the quality of air, water, natural habitats and critical ecosystems would be protected under the full force of the law. Just as important, in a $21^{\text {st }}$ century sustainable society, every human has equal access to basic needs like nutrition, shelter,education and health care. Economic systems are transparent, ethical and built on fair and equitable practices, and companies employ sustainable methods of production and distribution.

\section{THE ARCHAEOLOGICAL AREAS:}

An archaeological site is an instance of past human behavior or activity, where humans conducted some activity and left evidence of it behind. In general, Archeology is not exclusive in region from all of other regions. It is located 
everywhere in an important archaeological landmark that has been able to create civilization, creativity and greatness.

\section{The Concept of Historical and Heritage Areas:}

UNESCO defined them as those sites that include archaeological sites and buildings that constitute a human settlement in an urban or rural environment that recognizes its value from an archaeological, architectural, historical, aesthetic, social or cultural perspective. Therefore, the areas of historical and historical value must be considered in their entirety, including buildings, squares, gardens and streets, which are indivisible. The balance between them depends on the nature and consistency of their components. The type of use and activitiestherein are an essential part of the urban heritage. Along with architectural heritage. Thus, thetypes of trade, crafts and industries are an important part of the heritage and social considerations that need to be preserved and strengthened in heritage areas in accordance withinternational conventions in the field of preservation of urban heritage (Ali Hesham, 2013).

Historical and valuable areas are the areas associated with the cultural and cultural heritage. These areas have historical features distinguished both urban and architectural, whether they originated in different antiquity such as the Coptic or Islamic ages or those that arose during the nineteenth and early twentieth centuries. )Nasreen al-Lahham, 2007, P. 31(.

\section{The Concept of Archeology Scope:}

Known as homogeneous space, which has a particular character or character and is richin a collection of heritage items under the name of the law of antiquities protection, it containsvalues that characterize the characteristics of the community such as architectural values, architectural characteristics, customs and traditions ) 
Lubna Abdel Aziz, 2001(.

The Code of Civilizational Coordination also defines heritage domains as areas with rich heritage, urban, symbolic, aesthetic or natural value and needs to be treated as an integrated unit to preserve it (Official Gazette, on 11 May 2008, Law No. 119 of 2008).

Therefore, the heritage areas (historical) and surrounding areas must be considered in its entirety, including buildings, fields, gardens and streets, is an indivisible group, where the balance depends on the parts of the nature and consistency of its components. Thus, the types of trade, crafts and industries are part of the heritage and social considerations that need to be preserved and strengthened in heritage areas in accordance with international conventions in the field of preservation of urban heritage (Ismail Mohiuddin and Assaad Abu Ghazala, 2010).

\section{Policies to Protect Archaeological Buildings:}

Several measures must be taken to protect the archaeological buildings so that they aresafe from the deterioration of their condition, including (Majd Naji Al Masri, 2010):

- Conduct archaeological or heritage survey of the area to be protected to identify the importance of historic buildings and historical, artistic and archaeological monuments and thework of preliminary schemes and documentation and imaging.

- Preparation of lists of archaeological or heritage buildings to be protected for the issuance of decisions to maintain them, so that the archaeological or heritage buildings have become underthe umbrella of legal protection and therefore can be applied penalties prescribed by the laws.

- Intensive observation: Studies and legislation may not be sufficient to protect historic buildings. Heritage owners can carry out repairs that undermine their authenticity, historical, architectural and artistic value, such as using the 
INTERNATIONAL JOURNAL OF

MULTIDISCIPLINARY STUDIES IN ARCHITECTURE

AND CULTURAL HERITAGE

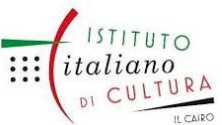

archaeological building to damage it.Sometimes, the archaeological building is destroyed. The establishment of a government or private building or steal its architectural and decorative elements to trade and smuggle it abroad. This is where regulations and policies are needed to protect it.

- Awareness: The definition of the citizen on the importance of cultural and economic effects for him and others and seize opportunities to raise interest in cultural heritage and notice responsibility.

Involve citizens to take responsibility for the protection of the cultural and heritage heritage by introducing them and participating in committees and governmental and private institutionsthat sponsor the matter to help raise awareness among citizens and occupants of heritage and heritage buildings, and contact with local and local authorities or central government authorities such as the various ministries and the Council of Representatives. And explained

the dimensions of the issue of heritage and its usefulness to the people and identity and therefore demand the allocation of funds necessary for the maintenance of these buildings andrationalize their uses and the issuance of legislation governing it.

\section{Proposed Criteria for the Establishment of Tourism Projects in Archaeological} Areas:

A set of proposals developed by a tourism organization from Botswana is in the stage of designing and implementing tourism projects to achieve sustainable tourism development in the archaeological and environmental tourism areas, as follows (Ibrahim Bazazo and Saida Afta, 2011):

\section{Environmental Impact Assessment:}

The environmental impact assessment of a project aims at identifying the impacts of the project on the environment and then identifying the necessary measures to reduce the negative impacts resulting from it and affect the environment 
in order to achieve the goals of sustainable development. The study of the environmental impact is to identify the elements ofthe environment and predict the magnitude of the damage caused by development and try to avoid or reduce the damage and mitigate the negative effects. This may involve the involvement of geologists, scientists, biologists, chemistry, agriculture, soil, economy, society, environment, water, management, forest experts, desertification, air pollution and other specialties that are commensurate with the size and nature of the problem.

The environmental impact assessment is not only to examine the final impact of the project but also to examine the damage caused by the construction equipment and infrastructurerequired from the start of the project until its completion, as well as to examine the impact of the mechanisms used and the resulting waste.

\section{Easy Access to the Site:}

Locations are relatively close to existing highways, airstrip and existing road network, with emphasis on environmental protection through minimum road construction and theprotection of environmentally sensitive sites.

\section{Coordinate the Site Using Local Plants:}

The use of local environment plants to enrich the landscape in the region, and the non-use of imported ornamental plants, taking into account that plants that require minimal water and require minimal maintenance should be used. This approach also helps to conservebiological diversity. Shade and lower temperature.

\section{Alternative Technology Options:}

Identify the most appropriate types of technology for ecotourism This can 
INTERNATIONAL JOURNAL OF

MULTIDISCIPLINARY STUDIES IN ARCHITECTURE

AND CULTURAL HERITAGE

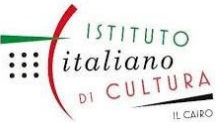

happen at alllevels for the development of facilities including water conservation and recycling, the use of solar panels and photovoltaic, and the use of wind energy.

\section{Use of Traditional Construction Methods and Local Building Materials (Natural):}

The use of local materials and traditional building techniques that are familiar and familiar to local workers, to reflect the local architecture of the area using local building materials such as wood, clay and stone in order to preserve colors that are consistent with nature. It is also possible to use recycled materials, and this approach may be a model of interestto the local population and contribute to the overall decline of energy consumption. With the use of local furniture manufactured from local materials such as wood and using local labor.

\section{Use of Fresh Organic Foods and Beverages:}

To ensure sustainability, it is best to have food and beverages from local products and should be fresh and organic. Organic foods are produced according to certain crop productionstandards, which means that they are grown without the use of traditional pesticides and industrial fertilizers, which are processed without radiation or food additives.

\section{Local Employment:}

Employing local workers is essential for achieving sustainable development, to achievethe desired economic benefits of the local community. The potential of local workers is recognized for their functional distribution in a way that is appropriate to their potential, allowing artisans and other producers and suppliers to exchange their craft. Thus enhancing thechances of protecting the ecological and cultural heritage and achieving economic sustainability by contributing directly to the 
economies of local communities without adverselyaffecting other aspects of their lives.

\section{CASE STUDY (MINIA GOVERNORATE):}

The province of Minia was called the bride of Upper Egypt, for its Mediterranean location and its length along the Nile River $135 \mathrm{~km}$ and the average width of $18 \mathrm{~km}$, as well asthe sites of archaeological sites. In addition, its $32,279 \mathrm{~km}^{2}$. The governorate of Minia is dividedinto nine administrative centers, which are rich in cultural, archaeological and urban heritage. They are from the north to the south: Adwa, Maghagha, Bani Mazar, Matay, Samalut, Minya,Abu Qurqas, The province of Minia is known by It is rich in archaeological diversity and rich in a huge number of temples, Pharaonic tombs, monasteries, churches, mosques, domes, shrines, historic palaces and other landmarks of the ages (Mahmoud Ahmed Darwish, 2005, p.5).

\section{Historical Overview of the Importance of Minia Governorate:}

Minia, a governorate of more than 4000000 population, is one of the most important and interesting tourist destinations in Egypt. It lies on the western bank of the River Nile, almostmidway between Cairo and Luxor. Minia government is an important agricultural as well as industrial region. Among its principal crops are sugar -cane, cotton, beans, soya beans, garlic, onion, vegetables of various sorts: tomatoes, potatoes, watermelons, and grapes. Minia governorate have a lot of Sharma

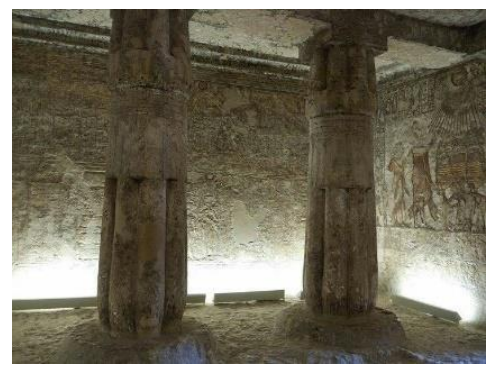


areas as Tal El-AMARNA with its rocks tombs and other remains, that's present name comes from that of local Bedouin tribe, the Amarna.

\section{Figure 1: The tomb of Meri Ra, the chief priest of Aton - Tal \\ Amarna}

Malawi has an interesting museum containing archaeological material from Hermopolis Magna, tuna el-Gabal and Meir areas, including many mummies, sarcophagi and statuettes of ibises which were worshipped there together with baboons as animals sacred to god Thoth, and also glass, pottery, faience, domestic equipment and numerous papyri (Mini Governorate and Tourism Promotion Authority, without history, p: 7).

Tuna El-Gabel lying 7 K.M of ElAshmunei, beyond the Bahr Youssef (a lake), here are

a number of tombs, dating from the Ptolemaic period (Minia Governorate and Tourism Promotion Authority, without history, p: 9) There is the best known structure is the unique tomb of the Family of Pet Osiris, which probably dates to the early Greco-Roman period. He was a high priest of Thoth. The tomb takes the form of a temple with an entrance portico and acult chapel behind. The burials are in underground chambers. It is unusual in that the tomb paintings, which depict scenes of daily life and of offering bearers, combine Egyptian and Greek styles, having for example, traditional Egyptian farming scenes but with people dressedin a Greek

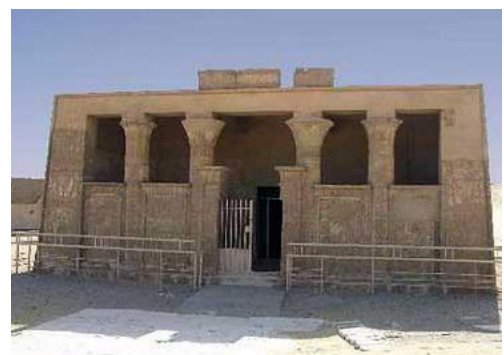

fashion (www.tourEgypt.net). 


\section{Figure 2: Façade of the tomb of Pet Osiris}

South of the tomb of Pet Osiris is a Greco-Egyptian city of the dead of the first centuryAD, with tombs and mortuary houses decorated in a complex mixture of Greek and Egyptian styles. Both the galleries and part of the necropolis were excavated by the Egyptian scholar, Sami Gabra, between the two world wars. Since then, Egyptian, British, German and Italian expeditions have worked here since the 1970s. Included here is the tomb of Isadora, who drowned in the Nile in about 150

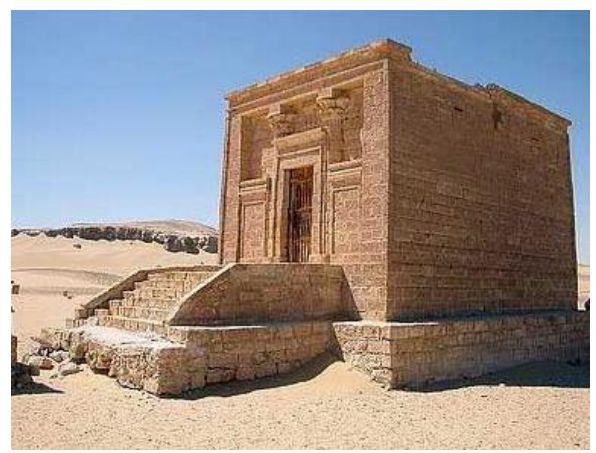

AD. Her mummy is still here.

Figure 3: The funerary house of Isadora

ABU-QURQAS is a district on the western bank of the Nile are the rock tombs of Beni- Hassan, $15 \mathrm{~km}$ east of Abu-Qurqas. You can access this area by boat from Minia or by car to Abu-Qurqas, then by boat to eastern bank of the Nile, or by car through the eastern road. Among the necropolis' 39 tombs dug into the cliff, only twelve were decorated with frescoes, which were created on a plaster coating

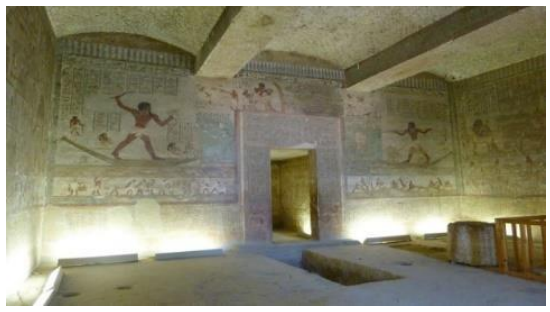

especially laid for this purpose. The typical decorationsrepresenting the daily and 
agricultural life during the Middle Kingdom have priceless archaeological value and provide precious information about this period of Ancient Egypt. Theornaments in the tomb of Khnoum hotep II, who was the monarch in the 12th dynasty, are particularly remarkable.

Figure 4: Khnoum hotep II tomb

The views from the cliffs of Beni Hassan are worth the trip alone, with a succession ofdesert, a draughtboard of cultivated fields, meanders of the Nile, a horizon broken by the bell towers of the churches and the minarets of the mosques

(www.easyvoyage.co.uk).

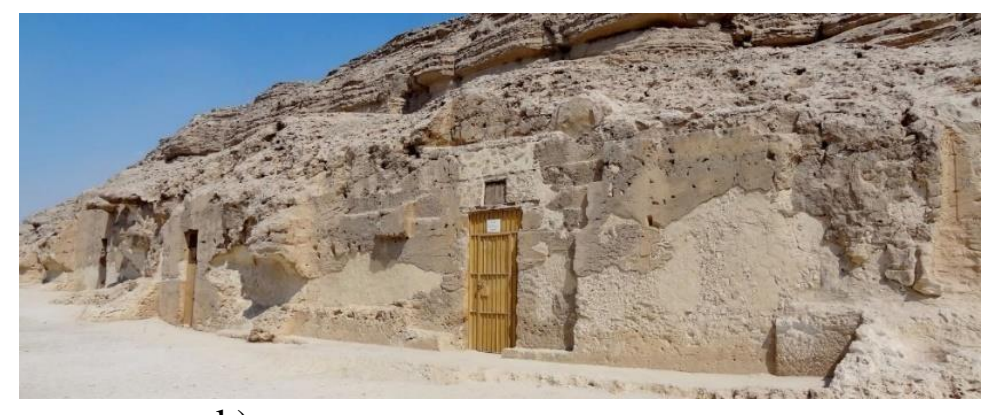

Figure 5: the rock tombs of Beni-Hassan

Chief town of governorate and a considerable commercial and industrial town, situatedbetween the Nile and the Ibrahimiya canal with a museum and mosque bof great historical importance, especially El-Wada mosque, the oldest mosque in Minia, and El-Lamati mosque from the Fatimid period.
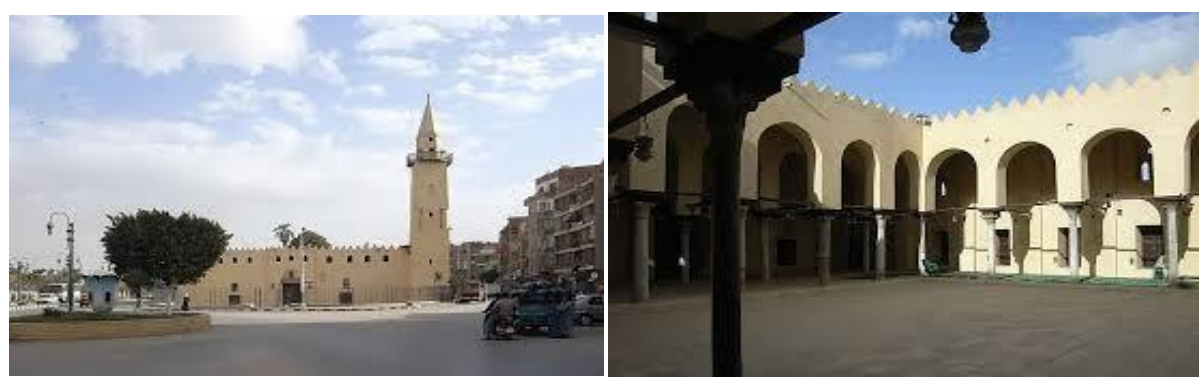
By the end of the $19^{\text {th }}$ century and the beginning of the 20th century, the upper-class families in Minia governorate: big landowners, merchants, and senior officials built splendid palaces and houses in districts and villages of governorate. About the most prominent palaces are those of Al-Shararaia Family in samalut, palace of fortineh- Malawi, and haiat elnofous palanse mallawi(Minia Governorate and Tourism Promotion Authority, without history, p: 33).

\section{The Tourist Attractions in Minia Governorate:}

It is one of the most beautiful governorates in Egypt in terms of availability of tourist attractions, whether natural, such as its unique location on the Nile River and its moderate climate most of the year and the appearance of the surface of the dry valleys (Mahmoud ahmeddarwesh,2005, p:36), and merge its land between the green lands and the deserts As well as itsrichness in archaeological diversity and its rich wealth of monasteries, churches, mosques, domes, tombs, pharaonic tombs and other landmarks of civilization throughout the ages. The large number of references travelers and historians have in their books and sources, there is almost no such books and sources from the city of Bani Khasib (present-day Minia) and the Bahnasa and Ashmounin and gabal al-tair.

It is also one of the most important monuments of Bani Mazar, and it extends its originsto the Pharaonic era. The dome of Bahnasa is one of its most important Islamic features. It alsocontains a mosque and the tomb of Hasan bin Saleh bin Zayn al-Abidin, the offspring of the Messenger of Allah Muhammad - peace be upon him - And the headquarters of the martyrs ofthe Islamic Army who participated in the opening of Egypt. The most important of what was mentioned by - Ali Pasha Mubarak in the conciliatory plans - that at the Islamic conquest of Egypt was Oxernhkos (Bahnasa) high walls high fortified walls and buildings and shields towers and pillars and has four doors to the authorities The four were for each door 
The towers between Ath towers and balconies were by forty churches and inextricably palaces), as well as a monastery Alsnkorah Prince Tadros Alhtaba Church.

As in the center of Mallawi, we find it also Zakhra of the ruins. The center of Mlawi comprises about one third of the ancient archaeological sites. The center is home to more than

80 villages, some of which are characterized by many distinct archaeological areas (Bakhshungi, p. 13). Which was the main center for the worship of the god Jehuti, the god of wisdom and knowledge of the ancient Egyptians, with important traces of Pharaonic, Greek, Roman, Christian and Islamic times, such as Amenemhat II, Amenhotep II, The ruins of the temple of Ptolemy II and Ptolemy III, as well as the monastery of Al Barsha, the tomb of Aha Nakht, the tomb of Jhoti Hattab, and the Sheikh Abbada region, east of the city of Mellawi, were erected in 120 BC. Ashmounin is $10 \mathrm{~km}$ away and contains sixty mud brick houses. Oneof the most important and famous of these houses or tombs is the cemetery of Petosiris, which was the chief priest of the god Thoth in the 4th century BC. This cemetery is characterized bymixing the Greek and the feminine, The tomb of Isadora Shahida The pure love of the beautifulgirl who lived In the era of Emperor Hadrian, she died drowning in the Nile River when she was crossing to the west bank of the river to meet her beloved. The Encyclopedia of Modern Egypt, issued by the Ministry of Culture in its tenth volume, stated that the mountain tuna is agroup of basements and underground corridors for the burial of birds and sacred animals. Thesecathedrals contain mummies for monkeys, Ibis and some falcons. There are also 9 booths from the Roman period Halim Abdel Nour,). The church of St. Fana is located in the monastery of Abu Fana, the Church of the Angel Gabriel Bahour, the Church of the Archangel Michael of Deir el-Mak in Biabadiya, the Church of St. Bishoy in Deir al-Barsha and the Church of St. Marjerjis, the Church of St. Johns, the Mosque of 
Yousif and the Mosque of Asqalani.

Investment Opportunities as the Vision of Minia Governorate That Reviving Tourism By:

Implementation of the proposed project to revive the path of The Holy Family. Minya governorate has three stations in its scope: Deir al-Tair monastery in Basalut, Al-Bahnasa in Bani Mazar, and Ashmounin in Mallawi and the three stations have cultural and archaeologicalheritage and can be exploited. The existence of many palaces that can be converted to museums that generate national income, such as the palace of souls in Mlawi and the group of palaces inMinya governorate (El Minia, Upper Egypt, issuing the governorate of Minya) by exploiting palaces and annexing them to sites of cultural and urban heritage. The opportunity to exploit the Nile islands, which are nature reserves can be employed to serve the tourism industry in the province. Reviving safari tourism and the camp, which is popular with a large sector of tourists, since Minya Governorate enjoys the presence of Western and Eastern Sahrawibackers. Development of the Museum of Mellawi and Museum of the artist Hassan Al-Sharq village Zawyet Sultan. Completion of the Athen Pyramid Museum, which overlooks the Nile and its ruins, which was inaugurated a year ago (The Tourism Office ofAl-Minia province, 2015).

\section{The Obstacles to Tourism Development in Minia as the Vision of Minia Governorate:}

The absence of a civil airport in Minia Governorate has deprived it of aviation tourism, especially the charter, which is the turn of the tourism companies in Hurghada. This is becauseof the lack of linking Minia to the important tourist sites in Egypt, as well as some Arab and foreign countries where there is a large number of Miniawia employment, Hajj and Umrah trips. 
1. Not operating the Sheikh Fadl Ras Gharib-Hurghada road to tourists because of the lack of insurance points, which impedes the attraction of large numbers of tourism in Hurghada to visit Minya, despite the great demand from tourist companies in Hurghada. The operation of this line tourism and providing services to them (petrol stations - - Ambulance - insurance) leads toincreased tourism flow in Minya, and encourage tourism investment on the desert areas on bothsides of this road.

2. The severe lack of tourism publicity for Minya as a result of the omission of the competent authorities in the State "Ministry of Tourism - Tourism Promotion Authority of the Ministry" for the work of publicity and tourism promotion external enough for the Central Egypt region,including Minia. The site of the official Egyptian Authority for the activation of the Elysee does not mention anything about Minya Or the Central Governorate of Egypt, and thearchaeological sites of these areas are not highlighted in the international tourist exhibitions. The whole focus is on Cairo, Luxor, Aswan, and beach tourism in Sharm El-Sheikh and Hurghada, as well as the lack of credit for activating and promoting tourism.

3. The completion of the Akhenaten Museum, located east of the Nile on the Nile, which is being established by the Ministry of State for Antiquities. This museum is expected to includeall the monuments of the Amarna archaeological period, which will increase tourist demand and increase the number of tourists in Minya Governorate.

4. The irregularity of the navigational line from Cairo to El-Luxor through Minya Governorate, where this line is stopped from time to time, which leads to confusion in the tourism companiesand deprives Minya of the influx of large numbers of tourists through this line. And an important antiquities on the banks of the Nile (Tal 
el-Amarna Monastery Mawas - Bani HassanAbu Bakras - Monastery of the Virgin Mary Basmalout - Sheikh Abada Balmawi). The visit of these sites through the Nile cruise numbers large numbers of tourists.

Non-allocation of budgets and the lack of special appropriations for tourist development andtourism investment in Minya, despite the presence of tourist and archaeological attractions, aswell as the existence of sites suitable for tourism investment in the vast areas of desert surrounding the archaeological sites outside the archeological properties. Interior and restrooms.

5. The absence of a sea port for Menya on the Red Sea coast, which is of great importance to the tourism industry and to maximize its benefit from several aspects:

Addition of another important feature of tourist attractions in Minia through this sea port helpsto achieve integration that meets the needs of multiple and diverse tourists. $=$ Encourage tourism companies to place tourist attractions in Minya in tourism programs.

Several tourism companies operating in the Red Sea have already demanded the transfer of tourist convoys in the Red Sea to tourist attractions in Minya. This order was previously raisedby the security authorities. This means that there is a growing demand for tourist attractions inMinya.

Increase the flow of tourism in Minia resulting in the opening of investment in many other economic activities related to the tourism industry, such as the establishment of more hotels and resorts and shrines and the consequent to provide a lot of employment opportunities, as it is known that tourism projects from the most areas that Characterized by labor intensity - this port opens the sea link Minya with a sea line with Saudi Arabia and thus the entire Gulf regionand benefit from this in the Hajj 
and Umrah trips. The transfer of workers in the Gulf

Encourage the people of Minya province to internal tourism to the shores of the Red Sea, whichleads to relieve pressure and overcrowding on the traditional beaches in Alexandria.

Opening the area for the people of Minia Governorate to invest in the areas that arise as a resultof the establishment of this proposed maritime port, and increasing the traffic on the road of Minya-Ras Ghareb opens the way for many investment opportunities in the field of tourism- agricultural-industrial-urban (The Tourism Office of Al-Minia province, 2015).

\section{RESULTS AND RECOMMENDATION:}

- The study reached a different arrangement from what was mentioned by many, or in a more precise sense, and reached a more accurate and completely complete itinerary than the points of the Archaeological Areas in Minia Governorate.

- Based upon a detailed analysis of the cases, the following positive outcomes can behighlighted:

- Lives of the local community changed considerably with the rural -tourism destination venture.

- The local people today have developed themselves into entrepreneurs.

- They have learned soft skills to handle customer service and to market their product.

- The entire rural/agri-tourism venture has raised the self-esteem of the farmers.

- Efficient utilization of the existing natural resources.

- Link the project to internal tourism by providing cultural event information and 
nearby historical landmarks to visitors and collaborating with local tourism organizations and festivals, thereby stimulating the local economy and creating more extensive economic linkages.

- Local people participation in conservation, promotion and sustainable development.

- Capacity building of local people

- Local culture, handicrafts, cuisine, dances, need be promoted

- Revitalization of crafts, customs and cultural identities.

- Increasing opportunities for social contact and exchange.

- Protection and improvement of both the natural and built environment.

- Increasing recognition of rural priorities and potential by policy-makers and economic planners.

\section{REFERENCES:}

- Emas, Rachel, 2015, the Concept of Sustainable Development: Definition and Defining Principles.

- Governments, Local , 2009 ,Planning for a Sustainable Future A Guide for Local Governments).

- Ismail Mohiuddin and Assaad Ali Suleiman Abu Ghazala, 21-23 December 2010, GIS technology as an effective tool for preserving and developing historic and valuable areas Case study, Cairo, 11th Eleventh International Engineering Conference.

- Lubna Mustafa Abdel Aziz, 2001, Promoting heritage heritage of value, documentation andevaluation of conservation experiences in historic Cairo , 
Master Thesis, Faculty of Engineering, Cairo University.

- Manal Abdel Muti, 2013, Lectures in Tourism Development, Alexandria: Dar El Wafaa Printing and Publishing-Alexandria.

- Mahmoud Ahmed Darwish, 2005, The antiques of Minya through the ages, Minia: Centerfor Research and Studies, University of Minya.

- Mensah, Adelina ; Castro, Maria, 2004, SUSTAINABLE DEVELOPMENT: A CONTRADICTION, Luciana Camargo.

- Mohammed Khamis Al-Zouka, 1999, The Tourism Industry from a Geographical Perspective, Dar Al-Maarifah Al-Jami'a.

- Mohab Darwish, 2010, Egypt and Nubia Countries History and Archeology of Nubia, Alexandria Library.

- NELSON, J. G., BUTLER, R. \& WALL, G. , 1993,Tourism and sustainable development:monitoring, planning, managing, University of Waterloo Department of.

- Nesreen Rafik Al-Lahham, 2007, Tourism Planning for Heritage Areas using EIA, Cairo:Dar El Nile for Publishing, Printing and Distribution.

- Ragheb, Riham A,2015, Sustainable Tourism Development : Assessment of EgyptianSustainable Resorts.

- Schmithüsen, F. , 2013, Three hundred years of applied sustainability in forestry.

- Unep-Wto, 2005, Making tourism more sustainable. A guide for policy makers.

- Ragheb, Riham A, 2015, Sustainable Tourism Development : Assessment of EgyptianSustainable Resorts, p:2 .

- Swarbrook, J. 1999,Sustainable tourism management, Wallingford, Oxon, UK ; New York

:, CABI Pub.

Faraah rashed, abo dalh yousef, December 2012. The role of tourism marketing in 
INTERNATIONAL JOURNAL OF

MULTIDISCIPLINARY STUDIES IN ARCHITECTURE

AND CULTURAL HERITAGE

ISSN: $2735-4415$

VOLUME 3, ISSUE 2, 2020, $31-61$.

www.egyptfuture.org/ojs/

supporting tourism development and reducing the crises of the tourism sector. Journal of economic and administrative research, Issue the twelfth issue.

Received: February 15, 2018

Accepted: April 20, 2018 